Western University

Scholarship@Western

1995

\title{
Monetary Explanations of the Weimar Republic's Hyperinflation: Some Neglected Contributions in Contemporary German Literature
}

David Laidler

George Stadler

Follow this and additional works at: https://ir.lib.uwo.ca/economicsresrpt

Part of the Economics Commons

Citation of this paper:

Laidler, David, George Stadler. "Monetary Explanations of the Weimar Republic's Hyperinflation: Some Neglected Contributions in Contemporary German Literature." Department of Economics Research Reports, 9521. London, ON: Department of Economics, University of Western Ontario (1995). 
ISSN:0318-725X

ISBN:0-7714-1838-8

\section{RESEARCH REPORT 9521}

Monetary Explanations of the Weimar Republic's Hyperinflation:

Some Neglected Contributions in Contemporary German

Literature

by

David E.W. Laidler and George W. Stadler

November 1995

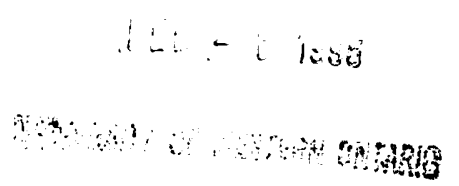
Department of Economics Social Science Centre
University of Western Ontario
London, Ontario, Canada
N6A 5C2
econref@sscl.uwo.ca




\title{
Monetary Explanations of the Weimar Republic's Hyperinflation: \\ Some Neglected Contributions In Contemporary German Literature*
}

\author{
by \\ David E.W. Laidler \\ Department of Economics \\ University of Western Ontario \\ London, Ontario \\ Canada N6A 5C2 \\ and \\ George W. Stadler \\ Department of Economics \\ University of Newcastle \\ Newcastle upon Tyne NE1 7RU \\ England
}

Revised November, 1995

*Laidler acknowledges the financial support of the Lynde and Harry Bradley Foundation, and the SSHRCC. All translations from previously untranslated (or poorly translated) German language sources are due to Stadler whose first language is German. This paper has been presented at a Workshop at the University of Western Ontario and at the University of Toronto-York University Workshop on the History of Economic Thought. The comments received on these occasions, and the advice of Phillip Cagan and Christof Rühl are gratefully acknowledged, but the usual disclaimers do, of course apply. Loretta Nott has provided capable research assistance. 


\section{INTRODUCTION}

It is generally believed that the monetary dynamics of hyperinflation were not well understood before the appearance of Costantino Bresciani-Turroni's Economics of Inflation (1931, tr. 1937), that the publication of Phillip Cagan's (1956) work on that topic represented a further major advance, and that Thomas Sargent's more recent analysis of the Ends of Four Great Inflations (1982) has made another substantial contribution to our knowledge of the phenomenon. The first of these works dealt exclusively with the Weimar Republic's Hyperinflation of 1921 1923 and that event figures prominently in the other two as well. In this paper we discuss some contemporary analyses of this experience, developed by German (or at least German speaking) economists, particularly Ladislaus (Ludwig) von Bortkiewicz, L. Albert Hahn, and Ludwig von Mises. ${ }^{1}$ We show that these commentators had a sophisticated grasp of the role of expectations in the inflationary process, in the cases of Bortkiewicz and Mises one that more nearly resembled that of Sargent, with its emphasis on forward looking behaviour, and the role played by the fiscal situation, than that of Cagan. Unlike Sargent, however, they regarded their insights in this regard as supplementing, rather than supplanting, the quantity theory as they understood it. We also show that, in analysing the influence of inflation expectations on price setting behaviour, these economists raised some issues that have no parallel in modern work on the Hyperinflation, but which may throw extra light on some phenomena associated with it, particularly the "shortage of money" that it appeared to create.

It is natural to ask why the work we refer to here has not previously attracted the attention we believe it merits. A number of inter-related reasons suggest themselves. First, as Feldman (1983) has pointed out, most recent research on the Hyperinflation has been carried out by non-German economists, who could not reasonably be expected to be familiar with what was, when 
all is said and done, a minority opinion within the body of German monetary thought. Second, the dominant view of the Hyperinflation among German economists of the period, usually characterised as the Balance of Payments Theory, was closely associated with the Real Bills Doctrine. According to this doctrine the role of the monetary authorities in the inflationary process amounted to no more than passively providing the money needed to meet the ever increasing needs of trade, as a depreciating exchange rate drove prices upwards. As this view, expounded by such prominent figures as Karl Helfferich (1923, tr. 1927), not to mention the Reichsbank itself, became discredited, so too did the whole German literature dealing with the inflation. The visibility of a contrary, quantity-theoretic view of matters, held and expounded by a minority of commentators, has not been helped by the fact that much of their work remains un- (or inadequately) translated, and in some cases, untranscribed from the difficult to read Gothic script in which it was first printed.

Also important in this context is the treatment of the work in question in the later literature of the interwar years. Howard Ellis (1934) does discuss it in his survey of German Monetary Theory, albeit briefly and somewhat disparagingly (cf. Ellis 1934, p. 217, 280, 294); but BrescianiTurroni, whose (1931, tr. 1934) study is still something of a standard reference on the economics of hyperinflation, either ignores or seriously misinterprets it: two of the three main contributors to the quantity theoretic explanation of the hyper-inflation whose ideas we shall discuss below, Hahn and von Mises, are referred to only once each in his book, the latter in a footnote. The third, von Bortkiewicz, attracts a full seven pages of commentary (cf. Bresciani-Turroni 1931 tr. 1937, pp. 175-182); but because Bresciani-Turroni, quite erroneously treats him as an opponent of the quantity theory, and indeed as an adherent of the "balance of payments theory", the commentary in question is completely out of focus and well calculated to deter anyone from attempting to read von Bortkiewicz's work for themselves. 
The outline of this paper is as follows: after a brief description of the key facts generated by the great inflation, we discuss the state of monetary economics in Germany before and shortly after the Great War, stressing the antipathy of the majority of German economists to the quantity theory of money. We then consider the questions which the Hyperinflation posed, and the answers which the then prevailing orthodoxy provided to them. We go on to review Cagan's quantity theoretic analysis of hyperinflation, and then deal with contributions, based upon the quantity theory, made by Bortkiewicz, Hahn and Mises in 1923-24. Finally, we present a brief summary of our major conclusions.

\section{THE STYLISED FACTS OF THE HYPERINFLATION}

The German inflation, which culminated in hyperinflation in 1921-23, generated five stylised facts for monetary theorists to explain: (1) a decline in the velocity of money during the war; (2) a phenomenal increase in prices, well in excess of the increase in the money supply from mid-1921 onwards; (3) a more rapid rise (depreciation) in the exchange rate than in domestic prices; (4) a widely perceived "shortage of money"; and (5) an extremely large increase in real balances in the wake of the stabilisation which brought inflation to an end.

Until the end of the war, prices tended to lag significantly behind the increase in the money supply. ${ }^{2}$ From bases of unity in 1913, prices increased to 2.17 by 1918 , but the money supply to 3.75. Thus, during the war the velocity of circulation declined significantly. The situation changed as soon as the war ended. Prices and the money supply began to rise significantly, so that by July 1921 both indexes stood at 14.3 . After mid-1921 prices began to rise much more rapidly than the money supply. By January 1922 the price index stood at 36.7 and the money index at 20.5. By the end of 1922 the two indexes stood at 1475 and 213.4 respectively, and the tendency for prices 
to surge ahead of the money supply persisted until stabilization was achieved in November 1923. This increase in prices far in excess of the money supply was mirrored by the behaviour of the exchange rate, which also rose (i.e. the currency depreciated) far more than the money supply, and, until 1923, more than domestic prices too. Furthermore, exchange rate movements generally tended to lead movements in domestic price levels. As to complaints of a shortage of money, these occurred as early as the winter of $1918-19$, when prices still lagged somewhat behind the money supply, but at this early stage they probably referred to a shortage of small change. After the Treaty of Versailles became effective in January 1920, such complaints became more frequent, and from December 1919 to March 1920 the price index rose from 8.03 to 17.1 while the money stock rose only from 8.27 to 9.8 . Though prices declined somewhat thereafter, this relief was but temporary. By 1922 hyperinflation was well underway, and complaints of shortages of money persisted until stabilization was achieved in 1923. Thereafter, a continuing large rise in the nominal money supply was absorbed with no increase in prices. ${ }^{3}$

The explanation of the first of the above-mentioned stylised facts, the decline in velocity during the war, was, and remains, uncontroversial. It rests on the breakdown of credit arrangements during the war which increased the demand for money, the extension of territory over which the Reichsmark was legal tender, and an increase in hoarding caused by wartime anxiety. The other four facts are, however, more contentious and central to the analysis which we shall discuss below. They were widely seen to be incompatible with the quantity theory of money and to support an alternative explanation of inflation that was sufficiently widely held as to merit the adjective "mainstream", or, as some contemporaries put it "official". 4 We shall now outline this mainstream view, placing it in the context of German monetary economics as it existed at the beginning of the Hyperinflation, and then proceed to show how exponents of the quantity theory reconciled their 
explanation with the above mentioned facts.

\section{GERMAN MONETARY ECONOMICS AND THE "BALANCE OF PAYMENTS" EXPLANATION OF THE HYPERINFLATION}

German monetary economics (and indeed German economics in general) during the first quarter of the 20th century displayed certain unique characteristics that are important to an understanding of the way in which the Hyperinflation was analysed. The German language was at that time used for scientific communication well beyond the borders of Germany itself, and German speaking Austrians, such as Schumpeter and von Mises, were by no means the only foreign economists to write in German. The Swedes, Knut Wicksell, and Gustav Cassel, for example, also did so. Even so, German language economics was far more cosmopolitan in outlook than German Economics. Within the German Empire, the subject was dominated by the Historical School, which taught (exactly contrary, for example, to the doctrines of Carl Menger and his Austrian disciples) that there were no universal scientific truths to be discovered within the discipline. All economic "laws" were specific to particular historical and institutional settings. The dominance of this viewpoint meant not only that the majority of German economists worked in an atheoretical descriptive tradition, but also, that they became inward looking, believing that they had nothing to learn from their colleagues abroad that could be relevant to a uniquely German experience.

The monetary field specifically was dominated by the Chartalist views of Georg-Friedrich Knapp as set out in his State Theory of Money (1905, tr. 1924). Knapp regarded money as the creation of law, and therefore of the state. He was concerned to understand the basis of the general acceptability of money in discharging debts, and argued that this derived from the legal authority of the state, rather than being, as Menger (1892) had argued, the unintended social consequence of 
individual maximising behaviour. It was a short step from this view to the position that the determination of the value of money, which was anyway of secondary importance to Knapp, was also a legal-institutional matter, rather than of that same individual maximizing behaviour; and so Knapp's Chartalism was quite antithetical to the quantity theory. ${ }^{5}$ Knapp himself characterised quantity-theoretic reasoning as "vulgar ignorance", and the majority of German economists, who usually characterised the quantity theory as asserting the proportionality of the price level to the quantity of money, seem to have agreed with him. This attitude towards the quantity theory is illustrated by a survey of German Monetary economics in the nineteenth century published in 1908 by S.P. Altmann. ${ }^{6}$ He concludes his discussion of the quantity theory by noting:

Nobody today contends that an increase in the money supply has a proportional effect on prices. The concept of changes in the value of money as a historical process is more and more generally accepted, a process that cannot be elucidated by the mechanical juxtaposition of money and goods, but requires the total, complicated organism of the foundation of society to be properly understood. (Altmann, 1908, p.49.)

German monetary economics may have been insular in its emphasis on Chartalism and its rejection of the quantity theory, but it nevertheless did find room for one important foreign idea, namely the "real-bills", or "needs of trade" doctrine, which argued that a banking system which confined itself to discounting only good quality short-term securities would thereby automatically provide only the money needed to facilitate the current volume of trade at current prices. It would thus run no risk of overissue, in the sense of an excess of money creation capable of causing prices to increase. This doctrine, whose origins go back to the 18th century had, as is well known, been 
much discussed in the writings of the British Banking School in the 1840's, and was thence transmitted to the German literature initially through the writings of Adolf Wagner, and, a little later those of Friedrich Bendixen, particularly during the wartime phase of the German Inflation. The real bills doctrine was a natural complement to the anti-quantity theory stance implicit in the state theory of money, and was also tailor-made as a defence against quantity-theoretic attacks on any non-monetary explanation of inflation, for one of its central implications is that monetary expansion is a passively endogenous consequence of rising prices, and in no sense their cause. ${ }^{7}$

In short, conventional German monetary economics as it stood at the beginning of the Hyperinflation offered no clear-cut theory of the price level to replace the quantity theory, but nevertheless argued that any observed relationship between money and prices was the result of "reverse causation". With the onset of inflation, of course, the first abovementioned feature represented a serious shortcoming. This deficiency was, however, addressed by referring to the behaviour of the exchange rate.

The most prominent exponent of what has come to be called "The Balance of Payments" Theory of the Hyperinflation, was Karl Helfferich. ${ }^{8}$ The final (6th) edition of his book Des Geld (Money) appeared in 1923, and contained extensive discussions of the hyperinflation. Helfferich argued that an adverse balance of payments (resulting from the difficulty of obtaining credit abroad and the necessity to import raw materials, difficulties exacerbated by the need to make reparations in kind to Belgium and France) caused the Reichsmark to depreciate on the foreign exchanges. The depreciation he then argued, resulted in upward pressure on prices and wages, which in turn created a shortage of money; in order to avert a complete breakdown in economic relations, the Central Bank was required to increase the circulating medium to facilitate transactions at the higher prices. As Helfferich put it: 
The race between wages and prices gave rise to a corresponding increase in the demand for money... The increase in the issue of paper money is, within this complex of phenomena, not the cause but consequence of rising prices and wages. (1923, tr. 1927, pp. 597-8.)

He went on to argue that because the currency depreciated by a far greater factor than the money supply rose, "the collapse of the German exchanges will be seen to be in no way related to the increase of the note circulation." (1923, tr. 1927, p.599).

Hence the appeal of the Balance of Payments Theory lay in the fact that, by having causality run from foreign exchanges to prices, it could explain the problem of the disproportionate rise in prices and the lag in prices behind exchange rates. It denied the existence of a causal relationship running from money to prices and was consequently quite compatible with prices rising faster than money. It could also account for the appearance of a shortage of money. Since the rise in prices was exogenous to domestic monetary conditions, it would result in a shortage until such a time as the money supply was increased, (inflated, in the terminology of the time) to accommodate the higher level of prices. ${ }^{9}$

Helfferich summarised his views as follows:

First came the depreciation of the German currency by the overburdening of Germany with international liabilities and by the French policy of violence. Thence followed a rise in the prices of all imported commodities. This led to a general rise in prices and wages, which in turn led to a greater demand for currency by the public and by the financial authorities of the Reich; and finally, the greater calls 
upon the Reichsbank from the public and the financial administration of the Reich led to an increase in the note issue. In contrast, therefore, to the widely held view, it is not "inflation" [of the currency] but the depreciation of the currency which is the first link in this chain of cause and effect. Inflation [of the currency] is not the cause of the rise in prices and of the depreciated currency, but the latter is the cause of the higher prices and of the greater volume in the issue of paper money. (Helfferich, 1923, tr. 1927, p.601.)

He contrasted this "balance of payments" explanation with what he termed "the theory of the classical English economists", according to which

An increase in the paper circulation causes a corresponding rise in the level of prices at home. These higher prices encourage imports and make export more difficult. They tend, therefore, to make the trade balance, and with it the balance of international indebtedness, unfavourable. When the latter balance is passive, the demand for foreign currency increases and the rates of foreign exchange are forced up. A glance at the figures given above shows, however, that this chain of reasoning does not apply; in fact, it is immediately obvious that in the case of Germany the increase in the note circulation did not precede the rise in prices, and also that the depreciation of the currency followed it but slowly and at some distance of time. The twenty-three-fold increase of the note circulation cannot possibly be the cause of the 10 times greater rise in prices at home and of the 15 times greater rise in prices of imports and of the dollar rate. (Helfferich, 1923, tr. 
1927, p.599.)

Moreover, it was not just data generated while inflation was rising that seemed to Helfferich to confirm his view. The simultaneous appreciation of the Mark and the large increase in the nominal money supply that took place in early 1923, just as Helfferich was completing his book, provided further support for his position: ${ }^{10}$

It is scarcely possible more clearly to prove that prices are independent of the quantitative factor of increase in circulation, and to demonstrate their dependence upon the course of the exchanges than by noting the fall in the level of prices and in the rates of exchange while the note issue was increasing in excess of anything previously known. (Helfferich, 1923, «. 1927, p.602.)

Now one matter should be stressed at this point. Helfferich's Balance of Payments theory of inflation was, in its own way, just as monocausal as would have been a quantity theory explanation that treated exogenous money growth as inflation's sole source. Such commentators as Graham (1930), Kindleberger (1994) and Feldman (1993) provide more than enough evidence to convince any reader that the hyperinflation was at least as much a socio-political as an economic phenomenon, and that the dislocation of Germany's export capacity associated with the war and its aftermath, not to mention the prospective burden of meeting punitive reparations obligations imposed at Versailles, put important economic and political limits on the Weimar Government's room for manoeuvre in economic policy. To this extent, balance of payments considerations must figure prominently in any account of the German inflation. As Graham points out, 
Causes and effects here as elsewhere were confused and reciprocal .... Note issues were a consequence of government deficits and government deficits depended largely on exchange rates and prices. Exchange rates and prices were thus an important causal factor in fixing the amount of notes in circulation at any given moment, yet at the same time they were affected in part, but in part only and to an indeterminate degree, by the past, present and highly uncertain prospective volume of such note issues. (Graham, 1930, p.56.)

But Helfferich's position is just as far removed in one direction from the kind of balanced eclecticism that we find in Graham or more modern work as would be a simple mono-causal application of a naive, exogenous money, version of the quantity theory.

Helfferich really did argue that

In considering the monetary conditions in Germany, the view widely held, especially abroad, is based on the pure quantity theory, and accordingly regards the increase in the circulation of paper currency in Germany as the cause of the rise in the level of German prices and of the depreciation of the currency. On closer examination, however, we find that cause and effect are here interchanged, and that the increase in the amount of paper money circulating in Germany is not in fact the cause but the result of the fall of the German exchanges and of the consequential rise in wages and prices. (Helfferich, 1923, tr. 1927, p.598).

The prime evidence he cited to support this position was the disproportion among changes in the 
exchange rate, the price level, and the money supply. ${ }^{11}$

\section{CAGAN'S QUANTITY THEORETIC MODEL OF HYPERINFLATION}

Now to a modern reader, the evidence that so impressed and indeed, in the opinion of many, misled many contemporary commentators on the German Hyperinflation into rejecting any causative role for the quantity of money is easily dealt with: it is only necessary to refer to the effects of inflationary expectations on the demand for real balances. Indeed, some elements of this explanation were understood before the event. Marshall (e.g. 1899) and Pigou (e.g. 1917) both noted from time to time that desired cash balances would be smaller if the currency was "liable to discredit", and closely related comments are to be found in Fisher's (e.g. 1911) writings as well. After the War, both Cannan (1921) and of course Keynes (1923) to whom Bresciani-Turroni paid particular attention, also discussed this phenomenon.

Even so, we are aware of no systematic attempt in this pre-World War I literature to develop these insights to the point of predicting that the rate of price inflation would systematically outrun the rate of growth of the quantity of money as an ongoing inflation gathered speed: small wonder, given the relative monetary stability of the gold standard era. After the War, Cannan and Keynes did begin to address this issue; but, though Bresciani-Turroni advanced matters further, if precise analysis, based on the postulate of a stable and continuous functional relationship between the demand for real money balances and the expected inflation rate is what is required, then it was only with the Cagan's (1956) "Monetary Dynamics of Hyperinflation" that they appear in the literature.

Cagan's study presents, as the reader will recall, a simple supply and demand for money model, in which the quantity of nominal balances is exogenously determined and the demand for real balances depends upon the opportunity cost of holding them as given by the expected inflation 
rate. The latter variable, in turn is measured as an exponentially weighted average of past inflation rates. Specifically, Cagan's model may be written

$$
\begin{aligned}
& m_{t}-p_{t}=\alpha\left(E_{t} p_{t+1}-p_{t}\right)+g \\
& E_{t} p_{t+1}-E_{t-1} p_{t}=\beta\left(E_{t-1} p_{t}-p_{t}\right),
\end{aligned}
$$

where $\mathrm{m}$ is the logarithm of the money supply, $\mathrm{p}$ is the logarithm of the price level and $\mathrm{E}$ the expectations operator. ${ }^{12}$

This simple system is dynamically stable if $\alpha \beta<1$, a condition which data generated by the German Hyperinflation (among others) seem to satisfy. ${ }^{13}$ Moreover, it easily accounts for one of the two stylised facts to which, in the 1920's, German adherents of the real bills doctrine pointed as being allegedly inconsistent with the Quantity Theory, namely that the German price level (and also the foreign exchange value of the Reichsmark) moved ahead of the quantity of money as inflation gathered speed. Clearly, in the system made up of equations (1) and (2), the higher is actual, and eventually therefore expected, inflation, the lower is the quantity of real balances demanded; hence as inflation rate increases the price level rises faster than the quantity of nominal money.

The Cagan model leaves something to be desired, however, when it comes to explaining the "shortage of money" phenomenon. Though it certainly predicts a shrinkage of the real money stock, it does so as a consequence of the voluntary choices of agents vis-a-vis their money holdings in the face of an increase in their opportunity cost. That agents should complain of actual shortages of money is not easy to reconcile with such voluntary behaviour. Now we are well aware of the 
pitfalls inherent in asking people what they think rather than observing what they do; but we note that, although remarks about the extra costs associated with managing a smaller, but still equilibrium, cash balance might be expected in Cagan's world, the frequency of references to "shortages" of money during the Weimar inflation suggest that agents often found themselves in possession of less cash than they wanted. Their complaints are easier to square with the existence of disequilibrium in the monetary system, with the supply of money (nominal and real) falling short of the demand for it, than with a simple voluntary and successfully executed decision to make do with a smaller inventory of cash. That, we believe, would be the verdict of anyone willing to treat the world "shortage" (Knappheit) as having its everyday connotation in this context.

\section{CONTEMPORARY EXPONENTS OF THE QUANTITY THEORY}

The Quantity Theory of Money was not entirely absent from the German language literature before the onset of hyperinflation. It had a prominent place in the first (1912) edition of Ludwig von Mises Theory of Money and Credit; ${ }^{14}$ and of particular importance was Joseph Schumpeter's (1917/18) paper "Money and the Social Product," which stemmed "... from the conviction ... that currency policy is a field in which there is no sense whatever in approaching practical problems before we have become clear on the fundamental questions of money ..." (Schumpter 1917/18, tr. 1956, p. 149). This paper provided a systematic account of the quantity theory along

"... the lines which have been traced in German by Menger, Wieser, Wicksell and Schlesinger; in Italian by Del Vecchio and Fanno; in French by Walras and Aupetit; in English by Marshall, Keynes, and in some points by Irving Fisher and Kemmerer." (Schumpeter 1917/18, tr. 1956, p. 149) 
Even so, only a few German or German speaking economists argued at the time that the hyperinflation was in progress that its root cause was excessive creation of money. As we shall now see, they relied on an analysis of inflation expectations to reconcile their position with the facts the hyperinflation generated, including the "shortage" of money. For simplicity, we shall refer to them loosely as the "German quantity theorists", although not all of them were German. As we noted earlier, three figures stand here: Hahn, Bortkiewicz, and Mises. Mises' main contribution to the literature which we shall now discuss appeared in 1923 (Mises 1923) and Hahn's in early 1924 (Hahn 1924a). These two, along with Bortkiewicz, also attended the 1924 meeting, dedicated to a discussion of the Hyperinflation, of the Verein für Sozialpolitik, an organisation of German-speaking economists similar to the American Economic Association, but founded earlier, in $1872 . .^{15}$

Bortkiewicz presented a paper at this meeting, while Hahn and Mises, along with Melchior Palyi, Felix Somary and Arthur Cohen, made important contributions to the discussion which took place there. Taken together, these sources enable us to form a clear picture of the way in which contemporary exponents of the quantity theory addressed the issues raised by the hyperinflation. As we shall see, Hahn's views differ from those of the other two, insofar as, like Cagan, he considered the Hyperinflation to be an equilibrium phenomenon, while Bortkiewicz and Mises viewed it as a disequilibrium phenomenon, in the sense that they regarded a discrepancy between the quantity of money supplied and that demanded as being one of its central features.

The economists who experienced the German Hyperinflation knew that its consequences for the real economy were serious. They understood that inflation tended to erode the functions of money, as a number of participants in the above-mentioned 1924 meeting of the Verein made clear. Thus Felix Somary noted that: 
At a particular level of depreciation in its value... money loses its functions as a standard of deferred payment and store of value; it remains a medium for prompt payment and may even lose this function in an advanced stage of inflation. (Somary, 1924a, p.246.)

More seriously, the inflation made investment calculations difficult, if not impossible, and so depressed investment and output generally:

I see the most important economic effect of inflation as the decline in production... In some branches of German industry costs fell to one quarter of world cost levels; under a stable currency this should have led to an inflow of foreign currency and an intensive boom in investment. The difficulty, perhaps even impossibility, of making investment calculations, particularly for new installations that take time to complete, reduced the number of those willing to undertake new investment. One could only calculate with any certainty for short periods, but with difficulty for long periods... I am convinced that an economic comparison must show that investment was usually low in Germany, and became even lower, the further the inflation advanced. (Somary, 1924a, p.246-7.)

Apart from making economic calculation difficult, it was also understood that inflation destroyed financial capital. Here, Melchior Palyi is worth quoting:

We have learnt this, if anything, from the inflation and its collapse: that so-called financial capital is as important a factor as any other in the modern productive system, and that its destruction can shake the foundations of the economy to the deepest level. (Melchior Palyi, 
1924a, p.253.)

These gloomy views of the real effects of the Hyperinflation are borne out by the statistics: an index of total output for Germany (1913=100) shows a fall from 80 to 61 from 1922 to 1923, when the Hyperinflation was at its height.

Confidence in the currency or, more precisely, expectations of changes in its value, were repeatedly stressed by the German quantity theorists as central to an analysis of the inflation. Hahn in particular emphasized the effect on the demand for money of expected inflation. For him, writing in 1924, just before the meeting of the Verein, "confidence", what he sometimes called "the qualitative factor" in determining the value of a currency, depended on the value of goods that currency could buy in the future, and thus on expected price inflation. ${ }^{16}$ Furthermore, expected future price movements, though they had similar effects on the desirability of money holding to interest rate changes, were likely to be more important.

Hopes of a rise or fear of a fall in the value of money means that a positive or negative premium is added to the real value of money. The effect is therefore principally the same as that of a rise or fall in the interest rate. However, there are two differences. Firstly, the effect of variations in confidence in the currency are usually much stronger, because they concern far larger margins, than for regular interest rate changes. For example, a currency depreciation of some magnitude is usually not only equivalent to a fall in the interest rate to zero, but is equivalent to a negative interest rate. (Hahn, 1924a, p.305.)

Hahn argued that the disproportionate rise in the price level which had to be explained was 
the consequence of an increase in velocity. As he never tired of pointing out, confidence in the future value of the currency determined the demand for it, and thus the velocity of money. As demand for money fell, and people began to economize on money balances, so prices, exchange rates, not to mention the bank money multiplier, would begin to rise, along with velocity:

The individual transaction detained cash balances for a shorter time period than previously. The phenomenon of a progressive depreciation in the value of money, causing reduction of cash balances - known from previous inflationary periods - manifested itself. This has the consequence that the quantity and velocity of bank money circulating in the economy can rise - and therewith the price level and foreign exchange rate - even if the quantity of banknotes in circulation does not rise accordingly, in other words, that prices and exchange rates rise faster than the quantity of notes in circulation. (Hahn, 1924a, p.295.)

Hahn continued by noting that the cause of the rise in velocity was the expectation of an ongoing fall in the value of money:

The reason for the manifestation of a rise in velocity of money is well known. On the expectation of continued losses associated with every kind of money holding, everyone attempted to exchange money, that until now he had been accustomed to retaining for longer or shorter periods, as quickly as possible - be it against commodities or foreign exchange - in order to transfer the loss involved onto the next recipient. A mentality developed towards the German mark that one can most succinctly describe as "playing a game of Schwarzer Peter". (Hahn, 1924a, p.295.) ${ }^{17}$ 
Thus Hahn whose analysis is in this respect similar to that of Cagan, and of Bresciani-Turroni too, saw the rise in velocity as the consequence of a dramatic decline in demand for money, as its store of value function (and thus its medium of exchange function) became increasingly eroded as the inflation progressed.

The position taken by Bortkiewicz and, as we shall see, Mises was rather different. Bortkiewicz did not deny that mistrust in the currency could lead directly to a rise in velocity, but he did not consider this to be important as a proximate cause of the disproportionate rise in prices. Instead, he argued that expectations of future note issues exerted an immediate impact on current prices. This in turn required money to turn over more rapidly to finance current transactions:

I readily admit that such a rise in the velocity of money occurs in reality. In addition I believe that mistrust in the currency plays a role in this; but I envisage the chain of causation in question differently to most authors who have recently approached this question. For I am of the opinion that mistrust in the currency, the expectation of further issues [of money] and the consequent fall in the value of money has an immediate impact on the price level, so directly strengthening the impact of an increased money supply. That in this manner the price level rises proportionally more than the money supply now causes a shortage of money, which one attempts to overcome by changing payments practices accordingly, and thereby, in one way or another, raising the velocity of money. This process of adjustment can eventually lead to a very considerable rise in the velocity of money. According to this, the rise in the velocity of circulation of money is not the cause of the sharper depreciation of money, but a consequence of the latter, a kind of adaptation to changed circumstances. (Bortkiewicz, 1924a, p.266.) 
Furthermore, Bortkiewicz saw the exchange rate adjusting faster than domestic prices and pulling domestic prices up behind them:

The foreign valuation of the currency of a country pursuing a policy of inflation [of the note issue] can manifest itself as a factor that drives up the domestic price level, especially if it is less favourable than is justified by the actual volume or tempo of issues of money. At a certain stage of the inflation it is the external value of the currency that determines the internal value, and not the other way round. (Bortkiewicz, 1924a, 266).

And, he went on,

"the true chain of causality is thus in my opinion: mistrust, resulting in a disproportionately large rise in exchange rates, consequently domestic prices and wages that have no relationship to the actual rise in the money supply, wherefrom - a further link in the causal chain - a shortage of money arises that then results in a rise in the velocity of circulation in one way or another. (Bortkiewicz, 1924a, p. 267).

This sounds suspiciously like a concession to the Balance of Payments theorists, and indeed this is precisely the misleading interpretation that Bresciani-Turroni was later to give to Bortkiewicz's theory. However, and crucially, Bortkiewicz explicitly criticized Helfferich for

... overlooking the fact that it is in the final judgement inflation [of the note issue] that 
stands at the beginning of the chain of causation. For how does lack of confidence, the unfavourable foreign valuation of the money of a paper-currency country arise, if not through an excessively large increase in its money supply? (Bortkiewicz, 1924a, p.267.)

By giving a central role to the impact of expectations of the future level of the money supply on exchange rates and prices, Bortkiewicz could thus explain the disproportionate rise in exchange rates and prices, as well as the shortage of money; and the lag in prices behind exchange rates followed naturally in this chain of causation as well. Bortkiewicz therefore explicitly concluded, contrary to Bresciani-Turroni's later account of his position, that one did not have to reject the quantity theory of money in order to explain the Hyperinflation:

One does not have to stand the Quantity Theory on its head in order to understand the disproportionality between the rise in the money supply and the rise in the price level that occurs at a particular phase of the inflation. It is far more valid to shape it into a version that takes account of the fact that the level of the value of money does not exclusively depend on the quantity of the actual note issue, but simultaneously on the expected volume of future issues. The expectations of the public with respect to the shaping of monetary circumstances in the future play a role here. Confidence or lack of confidence becomes relevant as an independent factor besides the actual quantity of money." (Bortkeiwicz, 1924a, pp.167-8, our emphasis.)

This suggestion that the quantity theory be reformulated to let prices depend on the expected money supply was echoed by Palyi: 
As far as the value of money is concerned, confidence means nothing less than the assessment of the probability of convertibility of the depreciated currency into gold. If the quantity theory omits this factor, it is incomplete and cannot - despite any references to changes in the velocity of circulation - accurately explain the course of events ... The difficulty for the quantity theory may possibly be overcome ... if it is stated in a form that not only the currently available circulating medium but also the quantity of money expected in the foreseeable future is also taken into account. (Palyi, 1924b, p.321.)

Although his argument was not couched in the mathematical rigor of the present day, this concept of forward-looking expectations surely represented a considerable insight on Bortkiewicz's part, and is similar to modern notions of rational expectations. The idea that the expected depreciation of the currency determines demand for it under inflationary circumstances is captured by Cagan's equation (1) above. However, if that equation is solved forward in the spirit of rational expectations theorising, one obtains

$$
P_{t}=\frac{1}{1-\alpha} \sum_{i=1}^{\infty}\left(\frac{\alpha}{\alpha-1}\right)^{i}\left(E_{t} m_{t+i}-\gamma\right)
$$

In this equation, prices today are seen to depend on the entire future time path of the money stock. To this extent Bortkiewicz's analysis of hyperinflation was closer in spirit to that of Sargent (1982) than of Cagan though unlike Sargent, he regarded it as extending, rather than supplanting, the quantity theory. 
Both Hahn and Bortkiewicz saw lack of confidence in the currency as driving velocity of money and prices up, but their analyses present two rather different views of the hyperinflationary process. Hahn, like Cagan (1956) saw hyperinflation as an equilibrium process, where prices rise once velocity, and thus aggregate demand, have risen, while Bortkiewicz (and here his analysis is very different from Sargent's) saw inflation as a disequilibrium phenomenon where "the expectation of further issues... has an immediate impact on the price level," so that prevailing prices do not necessarily bear any relationship to the current quantity of money. The Verein proceedings of 1924 record a rather futile debate between Bortkiewicz and Hahn, which seems to have arisen because neither author appreciated this difference between their points of view. In the paper he presented to the Verein, Bortkiewicz considered a simple numerical example, aimed at Hahn, which purported to demonstrate that the mere fact of consumers spending money more quickly would not necessarily alter velocity. ${ }^{18}$ The money might instead simply stay longer in the tills of producers, and it would require a reduction in the period between income payments before velocity rose (Bortkiewicz, 1924, p.263). Hahn replied that this example was unrealistic: during a time when money was losing its value, producers would be no more willing to hold extra balances than consumers, and velocity must rise. (Hahn, 1924b, p.303). Furthermore, Hahn argued that if lack of confidence in the currency was seen to bid up prices independently of changes in the money supply, then this would violate the quantity theory:

The quantity theory is in the first instance nothing more than a tautology that rests on the premise that, in a monetary economy, every transaction is made against money. Consequently, if the individual transaction takes place at higher prices, either more money must be available in the economy or money must perform its functions with greater speed.

If Herr Professor von Bortkiewicz assumes that confidence in the currency can be 
an independent factor that raises prices, then this violates the fundamental principle of the quantity theory insofar as every transaction can only occur with money. Only with money, and not with lack of confidence can one pay higher prices. Lack of confidence only works through the medium of a change in the velocity of money. This conclusion seems to me to be undeniable to anyone who reasons quantity-theoretically. (Hahn, 1924b, pp.303-4, our emphasis.)

In short, Hahn did not admit the possibility that $\mathrm{P}$ could rise unless MV rose simultaneously to permit higher prices. He missed the point that, for Bortkiewicz, hyperinflation was not an equilibrium process, that prices could be set in anticipation of a continuing rise in the money supply, and that the volume of transactions might be reduced as a consequence of a resulting shortage of money.

On this particular matter, Mises (1923) had already staked out a position similar to that of Borkiewicz. He too regarded the expected future time path of the money supply as capable of exerting an influence on the current behaviour of the price level over and above that of the quantity of money currently in circulation.

If the future path of the value of money is judged to be unfavourable, then, in anticipation of its expected decline in value, it will be valued at less today than would accord with the actual circumstances of money demand and supply. Prices will be set and paid that do not correspond to the present quantity of money in circulation and not to the present state of demand for money, but to future conditions. (Mises, 1923, p.6, our emphasis.) 
Hence, Mises saw both buyers and sellers as willing to transact at prices that depend on expected, not actual, monetary conditions. This way of looking at things had the virtue of also being able to explain the shortage of money: ${ }^{19}$

There is not enough money available at the moment to pay for prices that correspond to the expected future supply and demand for money. Hence trade begins to suffer from a shortage of notes: there is insufficient currency on hand for the completion of agreed transactions. The market mechanism, that brings about equality between aggregate demand and aggregate supply, no longer operates to create the exchange relationships that exist between money and other economic goods. One could see this clearly in the late Fall of 1921 in Austria. The completion of business transactions suffered severely from a shortage of money. (Mises, 1923, p.7.)

In such circumstances increasing the money supply further would only make matters worse and further fuel the inflation: ${ }^{20}$

Were one, as some people suggest, to increase the note issue even further, the situation would only deteriorate further. Because, in this case, the panic would increase further, the disproportionality between the depreciation of money and the quantity in circulation would become intensified. (Mises, 1923, p.7.)

\section{CURRENCY STABILIZATION AND THE VELOCITY OF MONEY}

One piece of evidence cited by Helfferich as demonstrating that the Hyperinflation could 
not have had monetary causes was the large rise in the nominal money supply that took place in February to April, 1923 when prices briefly stabilized and the currency appreciated. This particular episode was short-lived, but the same phenomena that marked it were also manifest after currency stabilization was initiated in November 1923. Commenting on similar stylized facts as they arose in Austria, Sargent has noted that

The phenomenon of the achievement of price stability in the face of a sixfold increase in the stock of "high-powered" money was widely regarded by contemporaries as violating the quantity theory of money, and so it seems to do. (Sargent, 1982, p.54.)

In the light of this comment, it is interesting to note that the German quantity theorists had no difficulty in accounting for the behaviour of real balances after the inflation came to an end, but did not regard that behaviour as incompatible with the quantity theory. Bortkiewicz, Hahn and Mises all realized that stabilization of the currency would reduce the velocity of money significantly.

During a deflation, said Bortkiewicz, the velocity of money would tend to fall as people increased their cash balances. This was not only a possibility in the case of an actual deflation, "but also applicable in the case of stabilization of the currency without shutting down the note-printing press, for which Austria provides an example. In this case a rise in the price level is avoided by the start of an intensive savings process." (Bortkiewicz, 1924a, p.273.) Mises also discussed Austrian experience at the 1924 meeting of the Verein:

The fact that the circulation of notes has grown considerably in the past year without 
rendering the maintenance of the actual convertibility of notes [into dollars] impossible for the Bank shows that today the economy needs more Austrian currency again; foreign money, which in the summer of 1922 had already satisfied a significant, possible even the greater part of the Austrian demand for money, has, now that confidence in Austrian monetary policy has returned, been replaced by Austrian money. (Mises, 1924, p.279.)

Referring to events in Germany during the period February to April 1923, when prices remained roughly constant, the currency appreciated, but the money stock doubled, Hahn commented that "this requires no further explanation. The phenomenon rested on the fact that as a result of the return of a certain confidence in the Mark, the velocity of circulation of bank deposits as well as of currency was reduced." (Hahn, 1924a, p.295.) Hahn also referred specifically to the stabilization programme itself. ${ }^{21} \mathrm{He}$ described the effect on money balances as follows:

If the velocity of bank deposits declines in consequence of a rise in confidence in the currency, so no alleviation [of the shortage of money] will initially occur - insofar as the reduction in velocity follows a maximum level - because the money base [Reichsbanksgeld] will also change its velocity...

A striking illustration of the case described here is provided by the unusual situation in the money market after the introduction of the Rentenmark. Because of the spontaneous reduction in the velocity of money from a maximum, no relief of the strain on the money market occurred for the time being, and money remained incredibly short [unerhört knapp]. First of all the cash boxes and cash registers filled themselves. Only when the cash 
registers and pocket book balances had acquired a normal level did money again take on the form of deposits with the banks, whereupon a quite extraordinarily strong relief of the situation in the money market certainly occurred, compared to the time before the introduction of the Rentenmark. (Hahn, 1924a, pp.310-11.)

Thus, the German quantity theorists saw a rise in confidence in the currency as increasing the demand for money, so reversing the process that had led to such a dramatic decline in real cash balances during the Hyperinflation. Unlike Sargent (1982), however, they did not view the disproportionate rise in the nominal money supply relative to prices after stabilization as a fact that violated the quantity theory of money.

\section{FISCAL POLICY AND SOCIO-POLITICAL FACTORS}

Sargent (1982) argues that a necessary condition for ending hyperinflation is a fiscal policy reform which obviates the need for inflationary finance. Examining the great inflations that occurred in Austria, Hungary, Germany and Poland after the First World War, he concludes that it was not merely a change in monetary policy per se, but the co-ordination of fiscal and monetary reform that ended these inflations. In each country an independent Central Bank was established that faced legal limits on the amount of unsecured credit it could provide to the government, and fiscal policies were instituted that moved the government's budget towards balance. In the cases of Austria, Hungary and Germany this was accompanied by a reduction in reparation obligations below those previously expected. Sargent's argument implies that a mere commitment to price stability by the Central Bank would not have been credible in the absence of a fiscal reform.

The economists whose work we have discussed in this paper were fully aware of the role 
the government finances played in stoking the inflation. ${ }^{22}$ Hahn argued that price stability can be maintained in the face of changes in the velocity of money provided the money supply can be aitered to offset such changes. Problems only began to arise when

... it is not possible to stop the increase in notes from entering circulation and to withdraw notes from circulation. This is particularly the case when the state begins to cover its expenditures with the help of the Central Bank rather than through taxation or issuing bonds. For in this case, the Central Bank does not have the opportunity to withdraw banknotes from circulation, because the debtor, the State, is normally not in a position to meet its obligations. As a general rule, the financial plight of the State is the cause why it, instead of financing its expenditures through taxes or borrowing, looks for access to the Central Bank that can cover its financial needs through ad hoc newly created purchasing power, usually provided in exchange for Treasury Bills. (Hahn, 1924a, pp.313-14.)

Furthermore, the best way of preventing a rise in velocity from increasing prices and depreciating the currency was "increasing the economic strength of the state through fiscal policies so that it can repay its floating debt." For, "if there are no more government bonds in circulation, they cannot be encashed at the Central Bank." (Hahn, 1924a, p. 314). Even so, Hahn did not view a fiscal reform as the sine qua non of ending inflation. He went on to say that if fiscal reform is impossible, an alternative solution might be to return to the gold standard, which would restore confidence in the currency.

The central importance of the government budget, and indeed the creditworthiness of the government, was emphasized, albeit in a rather clumsy way, by Arthur Cohen, who, in his 
discussion at the 1924 meeting of the Verein compared the finances of the state to those of an individual:

The depreciation of the currency is not a consequence of the increase in the quantity of paper money, but a consequence of a decline in its reliability [Bonität] in a credit-theoretical sense, in the quality of the debtor. The great risk that a holder of paper money runs expresses itself monetary depreciation. A decline in the value of money is, in a sense, a negative risk premium, analogous to a certain fraction of the interest rate being a positive risk premium. One only has to look at the balance of the Reichsbank, for example for the year 1922, and compare that to the actual budget of the Reich, to recognize that it is as in private life: if a private individual runs up too many debts, more than he can meet, then the claims against him will be dumped [verramscht] in the capital market. For a bill of 1000 , 10 may be paid. This is what happened to the Reichsbank as warden of the Reich's monies. (Cohen, 1924, p.288.)

However, Cohen conceded that the quantity of money did play a role in determining the price level, and went on to distinguish between a "direct" and an "indirect" quantity theory:

The cause of the depreciation of money is financial mismanagement, and the excessive quantity of money is a symptom of this.... the indirect [quantity] theory is the one that does indeed trace the decline in the value of money back to the inflation [of the money supply] but regards it only as a symptom and sees the real cause as financial mismanagement." (Cohen, 1924, p.289.) 
Bortkiewicz (1924c) agreed with Cohen that it was financial mismanagement that initially gives rise to inflation, noting that the circumstance that underlies financial mismanagement of this kind is invariably a war, regardless of its outcome. Indeed, in his view, the extreme fragility of Germany's socio-political fabric in the wake of Word War I may well have made inflation the most appropriate policy for the authorities to follow.

In monetary and in Central Bank policy one cannot separate the political from the economic factors and cannot overlook social factors either. It is no doubt proper to mention a remark by Privy Counsellor Harms here, who has generously abstained from speaking: the inflation saved us from a social revolution. I subscribe to this opinion, naturally without identifying myself with all the measures taken in the area of money and credit during the war and postwar period. (Bortkiewicz, 1924c, p.321.)

Mises too, who was, of course, a staunch opponent of inflation and an advocate of sound money, nevertheless, admitted that, given the socio-political conditions prevalent in Germany in the early 1920 s, inflating the currency to defray reparations payments had been unavoidable:

The German government has no alternative way of covering its reparations obligations. It would have no success if it tried to raise the sums demanded by issuing bonds or raising taxes. Given the way matters currently stand with the German people, a policy of compliance could not count on the consent of the majority if its economic consequences were clearly understood and they were not deceived as to its costs. Public opinion would 
turn with elemental force against any government that were to try to fulfil the obligations undertaken towards the Allied Powers completely. (Mises 1923, p. 31)

He thus suggested that the Hyperinflation was the best response available to the German government in the face of politically unacceptable demands for reparations. ${ }^{23}$

This view, that the monetary authorities of the countries vanquished in the first World War were simply overwhelmed by the socio-political consequences of their defeat, was echoed by Baron Alexander von Spitzmüller, Governor of the Austrian Central Bank throughout the Austrian Hyperinflation, which had ended in September 1922, more than a year before that of Germany. ${ }^{24}$ Spitzmüller confessed at the 1924 Verein meeting that, in theory at least, he had had the power to stop the note printing presses.

During the war the Austro-Hungarian bank was led by two people of impeccable gold standard credentiais... They, and also especially the Hungarian Finance Minister at the time, Teleszky, made the greatest effort to contain the inflation during the war, but without success. I think that this failure can be traced back to the process that Herr Goldscheid today called "being forced to accommodate to existing political imperatives." [Zwangsanpassung an bestehende politische Machtverhältnisse.] To a certain extent this was also true in the postwar period, when I functioned as Bank governor. I believe that the social conditions in Austria after the collapse [of the Empire in late 1918] were such that one could not have managed without inflation [of the money supply]. This shred of land that remained after the appalling wreckage, experienced social circumstances which, if one had also added restrictive monetary conditions, would undoubtedly have led to social collapse. I was the first to try to work against the inflationary tendency by stopping note 
issues; but that was out of the question. Then I pointed to my legal rights - that were, mind you, empty of any content, although I did in fact assert them - and declared that I could shut down the note-printing press any day. Thereupon I was told: Quite right, you will then create complete economic chaos [ein wirtschaftliches Tohuwabohu] for a week and then we will establish a state banking department, like they have in Czechoslovakia and Hungary. In other words, by shutting down the printing press I would have accomplished an act of futile heroism, without altering the long-term course of events in the slightest. (Spitzmüller, 1924$, p.312. $)^{25}$

\section{CONCLUSIONS}

In this paper we have shown that there were German economists, albeit a small minority, who, at the time of the Weimar hyperinflation, favoured a monetary explanation of the phenomenon. These economists understood that expectations of inflation would cause velocity to rise as inflation rose, and to fall again as stabilisation took hold. They had no difficulty in reconciling the behaviour of the exchange rate with their monetary explanation of inflation, nor did they find the "shortage of money" phenomenon puzzling. In addition, we have shown that they paid considerable attention to the fiscal situation of the Weimar Government as a factor undermining confidence in the currency during the inflation.

Their analysis was not worked out with the precision that would later mark Cagan's and, later still, Sargent's treatment of these topics. In particular, they offered no explicitly formulated model of how expectations about the future time path of prices and the money supply were formed. Even so, it does seem to be the case that, collectively, Bortkiewicz, Hahn, and Mises, anticipated many major insights of these later writers, and that Bresciani-Turroni, whose (1931, tr. 1937) book 
provides a critical link between the pre- and post-World War 2 discussions of the economics of hyperinflation was unjust in neglecting (and in the case of Bortkiewicz, misrepresenting) their contributions. They did carry matters considerably beyond Bresciani-Turroni's own starting point, namely the work of Marshall and Keynes. Nor do we have here a simple case of the anticipation of later ideas by earlier and now largely forgotten writers. Bortkiewicz and Mises in particular advanced a disequilibrium analysis of the effects of expectations about the future course of monetary policy on current price-setting behaviour which seems to have no exact parallel in modern work. It may be that, upon further investigation, the line of enquiry which they opened up will prove to be flawed. We intend to take no position on this matter when we suggest that such further investigation would nevertheless be worthwhile, and that the very fact that the literature we have here discussed contains these novel ideas makes it more than a historical curiosity. 


\section{ENDNOTES}

1. Bortkiewicz, of Polish origin, but educated at the University of St. Petersburg in Mathematics and Physics, is nowadays remembered, if at all, as a critic of the capital theory of Bohm-Bawerk and Marx, as a contributor to the Marxian Theory of relative values and prices and as a statistician who applied the Poisson distribution to the analysis of the frequency of deaths from horse-kicks among Prussian cavalrymen. The clumsiness of his nevertheless penetrating analysis of inflation reflects the unspecialised nature of his knowledge of monetary economics. Hahn was as banker based in Frankfurt am Main, who became well known later in the decade for a particularly lucid exposition of the process of bank credit expansion, and an analysis of the role of the banks in trade cycle, which followed Schumpeter in concentrating on their role in financing innovation, but went beyond Schumpeter in presenting an optimistic (almost inflationist) view of their powers to promote real expansion. In the post-World War 2 years, he participated prominently in debates about the reconstruction of the German monetary system. Mises, nowadays still well known, was at this time a Privatdozent at the University of Vienna and economist for the Vienna Chamber of Commerce. In 1926 he founded the Austrian Institute for Business Cycle Research, with which his former student, Friedrich von Hayek, was also associated as a junior staff member. The second edition of his famous Theory of Money and Credit (1st ed. 1912), later translated into English (1934) and still read today, was published in 1924, the same year as the meeting of the Verein für Sozialpolitik whose proceedings are a central point of interest in this paper.

2. Data mentioned in this paragraph are taken from Table XIV of Frank Graham (1930).

3. Throughout the Hyperinflation, the Reichsbank's discount rate remained ludicrously low. In 1922 prices rose by about 4000 percent, but the discount rate stood at five percent per annum until July, (the same level it had been since the early days of the War) whereafter it was gradually raised to ten percent in the second half of the year. An even greater chasm appeared between the discount rate and inflation in 1923. By July 1923 the discount rate had been raised to eighteen percent per annum, but in that month alone prices rose by over 440 percent. By October 1923 the discount rate stood at 90 percent, but between the 2nd and 30th October, at the height of the Hyperinflation, prices rose by a factor of 221 and continued to gallop ahead until around 20 November, when the stabilization began to take effect. The Reichsbank did not restrict itself to discounting only treasury bills at these interest rates, from mid-1922 onwards it also discounted rapidly increasing quantities of commercial bills. Under the circumstances, this policy amounted to granting a transfer payment to those agents lucky enough to have their bills accepted by the Reichsbank.

4. Referring to the Balance of Payments theory, Bortkiewicz says that "...only recently are there signs of a clear rejection of this official and semi-official view of the ruin of our currency." (1924a, p.267). See also Footnote 8 below. 
5. S. Herbert Frankel argues that in regarding money as extraneous to society, an extra member that is grafted on by the state, Knapp is making a category mistake, that is, "representing facts 'as if they belonged to one logical type or category when they actually belong to another.' " (Frankel, 1977, p.10.) In Frankel's view money is a component of the social order on the same level as those other institutions which we call "the state". It is in no sense subordinate to them.

6. Further evidence of the slight regard in which the quantity theory was held is provided by Howard Ellis and Schumpeter. In his survey of German monetary economics, Ellis (1937) talks of "the traditional anti-quantity theory alignment of German economics" (p.183), while Schumpeter (1954) also implies that the work of eminent German economists was antithetical to the quantity theory and did not move monetary theory in Germany forward in a way comparable to developments in, say, Britain , America or Sweden. Discussing monetary economics from 1870 to 1914 and beyond he states:

For Germany, I will mention two of the period's best men on money and monetary policy, though they do not present themselves favorably in their arguments against the quantity theorem - which were in part developed for the particular purpose of showing that the fall in prices, 1873-98, had nothing to do with gold production or the extension of the area of the gold standard. ... (Schumpeter, 1954, p.1104n.)

The two men concerned were Erwin Nasse and Wilhelm Lexis. There was some debate in Germany as to how much responsibility Knapp bore for the Hyperinflation. The consensus seems to be that Knapp himself did not advocate inflation, but that his State Theory fostered an antitheoretical climate (Bortkiewicz, 1924b, Melchior Palyi, 1924b, Felix Somary, 1924b). However, there is no doubt that some of Knapp's followers "did indeed advance inflationary measures" (Ellis, 1937, p.19).

7. Schumpter $(1954$, p. $707, \mathrm{fn}$.) says that "the German enthusiasm for Tooke as a theorist was, I think, in great part due to the influence of Adolf Wagner." (emphasis in original). Note that, in addition to being an exponent of Banking School ideas, Bendixen was second only to Knapp as a creator and exponent of the state theory of money. (See Schumpeter $1917 / 18$, tr. 1956, p. 149, fn.) On the role of Banking School ideas in German Monetary Economics, see also Ellis (1934) p. 180 et seq.

8. Helfferich had been a student of Knapp, but he was not an exponent of the state theory of money. Even so, as Theodore Gregory remarked in is "Introduction" to the 1927 translation of Money (Helfferich 1923, tr. 1927), "Helfferich's mind was largely occupied with refuting specific arguments put forward by Knapp, though his attitude is perhaps at times more coloured by Knapp's terminology and opinions than he was himself aware of." (Gregory, 1927, p. viii)

Helfferich was Secretary to the Treasury and Secretary of the Interior during the First World 
War, and a Reichstag deputy from 1920 until his death in 1924. Palyi comments: "But even in the spring of $1923 \mathrm{Dr}$. Helfferich declared in the Reichstag that there exists no inflation [of the money supply] in Germany, so expressing the predominant view of the currency's dependence on the balance of payments." (Palyi, 1924a, p.250, our emphasis.).

9. The use of the word "inflation" as meaning growth in the price level is fairly recent. The fifth edition of the Concise Oxford Dictionary (1967) defines inflation as "an undue increase in the quantity of money in relation to goods available for purchase." This is the sense in which both German speakers like Helfferich as well as English speakers like Ellis and Young use the term. We append the phrase "of the money supply" or "of the note issue" in brackets after the word "inflation" in several quotations used below to clarify matters for the reader.

10. Note that this episode was a brief one, and should not be confused with the stabilization of late 1923-1924. The evidence it generated was, however, qualitatively similar. From February to April 1923 the price level remained roughly stable and the currency appreciated, but the money supply almost doubled.

11. Helfferich was by no means alone in drawing attention to this evidence. For example, the American economist Allyn Young, having served as the principal economic advisor to the American delegation at Versailles, was familiar enough with the German situation to see that Government debt problems, rather than balance of payments issues per se lay at the heart of her economic problems, and he was no exponent of the real bills doctrine. Nevertheless, in 1923, with reference to Europe in general he wrote

that the sequence of cause and effect, particularly in the period following the war, has not been inflation [of the note issue], unbalanced budgets, disordered exchanges, but unbalanced budgets, disordered exchanges, inflation. (Young, 1923, p.902.)

In the specific case of Germany he cited the same phenomena as did Helfferich to support this interpretation of events:

But the prices in marks of imported and exported goods - of goods, that is, for which there is an international market - were driven rapidly up by the advance in the price of foreign exchange. Tied to the prices of the international market in a thousand indirect and intricate ways, the domestic price level, though until recently lagging considerably behind, advanced haltingly but irresistibly. Inflation [of the note issue], though accelerated by an unbalanced budget, followed - it did not precede - the advance of prices. During the past four years the per capita circulation of money in Germany, measured in terms of its domestic purchasing power, has been much smaller than before the war. Measured in terms of its gold value the shrinkage of the currency has been even more striking. In large 
measure inflation [of the note issue] has been the result rather than the cause of the depreciation of the value of the currency. (Young, 1923, p.403.)

See Mehrling (forthcoming) for a comprehensive account of Young's monetary economics.

12. Cagan (1991) has revisited his study recently, and makes the following remark:

"While the use of adaptive measures of expected price changes in estimating the money-demand function in hyperinflation does not appear far from reality, a more serious problem ... is that the money stock cannot be treated as exogenous. A plausible way to endogenise the money stock is to model the revenue needs of the government for an inflation tax. Unfortunately, no one has successfully shown how to express those needs and their realization as a function of independent variables." (Cagan 1991, p. 559, fn.)

The main thrust of Cagan's paper is to show that adaptive expectations perform well in a demand for money function, relative to rational expectations, as exemplified by Frankel's (1977) use of the ratio of the forward exchange rate of the Reichsmark to its concurrent spot rate. Cagan interprets this result as the consequence of "rational learning" in the face of a major, initially unperceived, long-run shock to the time path of inflation.

13. Although Cagan's point estimates for $\alpha \beta$ exceeded unity for Germany and the Soviet Union's hyperinflations, Khan (1975) found that correcting for residual serial correlation results in point estimates of $\alpha \beta$ of less than one for all the seven hyperinflations studied by Cagan.

14. Note that this edition of Mises' work remains untranslated. The second edition, (Mises 1924, tr. 1934) a considerably extended and revised work, is available in English.

15. Unlike the other contributions discussed here Mises' 1923 paper has been previously translated into English under the title "On the Manipulation of Money and Credit". We prefer to use our own translation, however, because this 1978 translation has been re-edited, with for example, section headings inserted that are not in the original paper. It also misses the subtlety of Mises' meaning in several places as readers will see if they compare some of our translated passages to those of Greaves. To give but one example, the German word for chartalism is mistranslated as "chartism" $(1978, \mathrm{p} .24)$, so rendering the meaning of the text obscure. The editor seeks to remedy this obscurity in a footnote by pointing out that chartism, a 19th century British social protest movement held principles antipathetic to those of Mises, so adding to the confusion. In fairness to the translator, this text is clearly aimed at a contemporary audience rather than historians of thought. 
16. The view expressed by Palyi on this topic is also worth noting.

... changes in the quantity of money and the velocity of circulation cannot completely explain the inflationary effects on prices and exchange rates. One must rather consider the factor of confidence, that is, the expectation of convertibility of the depreciated currency (into gold in practice). (Palyi, 1924a, p.254.)

17. In the German card game Schwarzer Peter the objective is to rid oneself of a particular card by passing it on to other players. The player holding it when the game ends is the loser.

18. Much of Bresciani-Turroni's critique of Bortkiewicz is aimed at this numerical example.

19. Mises was clear that this was not a shortage of money as the term was conventionally understood, i.e. as a shortage of credit:

This shortage of money should obviously not be confused with what a businessman normally understands by a monetary shortage, which is accompanied by a rise in the interest rate for short-dated investments. (Mises, 1923, p.7.)

20. Mises expresses himself in a remarkably similar vein in the second edition of The Theory of Money and Credit, which appeared a year after his Verein paper. Indeed, he seems to have lifted passages from the Verein paper almost verbatim. See particularly, pp. 228-29 of Mises (1924 tr. 1934).

21. The Rentenmark was introduced on 20 November 1923.

22. The German quantity theorists saw the root of the inflation as lying in the financing of the Great War, because the government had resorted to the printing press for this purpose. However, they differed as to whether inflation of the money supply had been essential to finance the war.

23. Mises' view receives some support from other sources. In his classic study of the German inflation, Frank Graham says that

"...the will to check depreciation in Germany was much weaker than in other countries since the Germans were convinced, by no means without justification, that improvement in the public finances would lead to still more severe exactions on the part of the victors in the war." (Graham, 1930, pp.4-5).

It would be wrong, however, to assume the Hyperinflation was the result of a cynical calculation by the German government. It was a time of "frequent changes of government, but also of repeated putschist efforts, political violence and assassinations." (Feldman, 1993, p.310) Feldman concludes that 
p.310) Feldman concludes that

"Germany's leaders certainly did not plan either the inflation or the hyperinflation. In the face of extreme domestic and international constraint, however, they either found it necessary or chose to exploit inflationary opportunities at crucial points, especially in the fall of 1922, and failed to take appropriate measures to control the avalanche." (Feldman, 1993, p.838).

24. The reader might note that one Finance Minister of the Social Democratic Austrian Government whom Spitzmüller served was, between Spring and Fall 1919, none other than Joseph Schumpeter.

25. The German original uses the adjective herostratisch which we translate by the phrase "of futile heroism". Langenseheidt's Encyclopaedic German-English Dictionary defines a herostrat as a wanton seeker after fame or glory. The suggested translations of the adjective herostratisch are wanton or ruthless, which rather seem to lose some of the original meaning. It is also interesting to note that, as Sam Hollander has pointed out to us, that he word Tohuwabohu is the Hebrew word for chaos, used in the account of the Creation given in Genesis. 


\section{BIBLIOGRAPHY}

Altmann, S.P. (1908) "Zur deutschen Geldlehre des 19. Jahrhunderts," in Festgabe fr Schmoller: Die Entwicklung der deutschen Volkswirtschaftslehre im 19. Jahrhundert, Leipzig Vol.1, sec. VI, pp.1-67.

Bortkiewicz, Ladislaus von (1924a) "Die Ursachen einer potenzierten Wirkung des vermehrten Geldumlaufs auf das Preisniveau," Verein für Sozialpolitik: Schriften, 170, pp.256-274.

Bortkiewicz, Ladislaus von, (1924b) Discussion Verein für Sozialpolitik: Schriften, 170 pp.290-91.

Bortkiewicz, Ladislaus von, (1924c) Schlußwort Verein für Sozialpolitik: Schriften, 170 pp.317-21.

Bresciani-Turroni, C. (1931) The Economics of Inflation (as tr. by M.E. Sayers, 1937, reprinted, New York, Agustus-Kelley, 1968).

Cagan, P. (1965) "The Monetary Dynamics of Hyperinflation," in M. Friedman (ed.) Studies in the Quantity Theory of Money, Chicago, University of Chicago Press.

(1991) "Expectations in the German Hyperinflation Reconsidered," Journal of International Money and Finance 10, (December) pp. 552-560.

Cannan, E. (1921) "The Application of the Theoretical Apparatus of Supply and Demand to Units of Currency," Economic Journal 31, 453-461.

Cohen, Arthur (1924) "Discussion", Verein für Sozialpolitik: Schriften, 170 pp.287-90.

Ellis, H. (1934) German Monetary Theory 1905-1933 Cambridge Ma.: Harvard University Press. Feldman, Gerald, D., (1983) "The Historian and the German Inflation," in Nathan Schmukler and Edward Markus (eds.), Inflation Through the Ages: Economic, Social, Psychological and Historical Aspects, New York: Brooklyn College Press.

Feldman, Gerald, D. (1993) The Great Disorder: Politics, Economics and Society in the German Inflation, 1914-1924, Oxford: Oxford University Press.

Frankel, S.H. (1977) Two Philosophies of Money, Oxford, Blackwell. 
Frenkel J. (1977) "The Forward Exchange Rate, Expectations, and the Demand for Money: The German Hyperinflation," American Economic Review (67) Sept. 653-670.

Graham, Frank D. (1930) Exchange, Prices and Production in Hyper-Inflation: Germany, 1920-1923, New York: Russell and Russell.

Gregory, T.E. (1927) "Introduction," to Helfferich (1923, tr. 1927).

Hahn, L. Albert (1924a) "Zur Frage des sogennanten 'Vertrauens in die Währung,'" Archiv für Sozialwissenschaft und Sozialpolitik, 52, 2, pp.289-316.

Hahn, H. Albert (1924b) "Discussion". Verein für Sozialpolitik: Schriften, 170, pp.301-6.

Helfferich, Karl (1923) Money, 6th ed., tr. L. Linfield, Adelphi, New York, 1927.

Keynes, J.M. (1923) A Tract on Monetary Reform London, Macmillan.

Kindleberger, Charles P. (1994) "The Great Disorder: A Review," Journal of Economic Literature, 32, 3, (September) pp. 1216-1225.

Khan, Moshin S., (1975) "The Monetary Dynamics of Hyperinflation: A Note," Journal of Monetary Economics, pp. 337-60.

Marshall, A. (1899), "Evidence to the Indian Currency Commission," reprinted in J.M. Keynes (ed.) Official Papers of Alfred Marshall, London, Macmillan, 1926.

Merhling, P. (1993) "The Monetary Thought of Allyn Abbott Young," Barnard College, mimeo. Mises, Ludwig von, (1923) "Die Geldtheoretische Seite des Stabilizierungsproblems," Verein für Sozialpolitik: Schriften, 164, pp.1-37.

Mises, Ludwig von, (1924) "Discussion," Verein für Sozialpolitik: Schriften, 170 pp.275-80. (1924, tr. 1934) The Theory of Money and Credit (2nd ed., English tr. by H.E. Batson, London, Jonathon Cape, 1934).

Palyi, Melchior (1924a) "Referat," Verein für Soziatpolitik: Schriften, 170 pp.249-255.

Palyi, Melchior, (1924b) "Schlußwort," Verein für Sozialpolitik: Schriften, 170 pp.320-23. 
Pigou, A.C. (1917) "The Value of Money," Quarterly Journal of Economics 32, 38-65.

Sargent, T.J. (1982) "The Ends of Four Big Inflations in R.E. Hall (ed.) Inflation: Causes and Effects, Chicago, University of Chicago Press.

Schumpeter, Joseph (1917/18) "Das Sozialprodukt und die Rechenpfennige," Archiv für Sozialwissenschaft und Sozialpolitik, 44, pp.627-715. (tr. 1956 by Arthur Marget as "Money and the Social International Economic Papers No. 6, London, Macmillan, pp. 148-211). (1954) History of Economic Analysis New York, Oxford University Press.

Somary, Felix, (1924a) "Referat," Verein für Sozialpolitik: Schriften, 170, pp. 244-49.

Somary, Felix, (1924b) Schlußwort, Verein für Sozialpolitik: Schriften, 170, pp.323-25.

Spitzmuller, Alexander Baron von, (1924) "Discussion," Verein für Sozialpolitik: Schriften, 170, pp. $310-13$. 